\title{
A Research of the Environmental and Social Effects of the Adoption of Biotechnological Practices for Soybean Cultivation in Argentina
}

\author{
Guido Fernando Botta $^{1,2}$, Alfredo Tolón-Becerra ${ }^{3}$, Xavier Lastra-Bravo ${ }^{3}$, Mario Cesar Tourn ${ }^{2}$ \\ ${ }^{1}$ Technology Department, National University of Luján, Luján, Argentina; ${ }^{2}$ Agronomy Faculty, Buenos Aires University, Buenos \\ Aires, Argentina; ${ }^{3}$ Ctra Sacramento, University of Almería, Almería, España. \\ Email: sad@s6.coopenet.com.ar
}

Received July $18^{\text {th }}, 2011$; revised August $14^{\text {th }}, 2011$; accepted September $25^{\text {th }}, 2011$.

\begin{abstract}
In recent years, the excessive and unregulated implementation of biotechnological practices has placed a large number of farmers in a precarious position throughout our country. Here we review and we analyzed results produced in field experiments installed along the Argentinean Pampas to determine environmental and social effects of the adoption of biotechnology practices associated with direct sowing (DS) of soybean. The use of machinery for farm work, the perfection of handling techniques, the incorporation of improved seeds, and the use of fertilizers and pesticides together influenced a significant increase in the productivity of the land, manual labors and capital. Despite positive economic results of this agricultural renewal also brought about consequences that proved to be detrimental to producers. By the end of the 1980s numerous sectors were in states of crisis. The major findings of our research are: 1) exhaustion of resources; 2) erosion problems brought on by inappropriate land use and soil compaction by increased area under DS system; 3) loss of biodiversity in the ecosystem; 4) crisis among family-owned farms who cannot access to new improved technologies due to profitability, obsolete machinery and the impossibility of access to credit; 5) reduction in smaller farms; 6) increase in specialized production, which implies the subordination of farming production to the dynamic of capital and finally more direct relationships between the entities generating technology and primary productions. The results of our study on adoption of biotechnology practice associated to DS of soybean give the following results: 1) the deterioration of family income from farms reached $41 \%$ per hectare comparing the average values of the 1990s to the 1980s. Farms smaller than 190 hectares, therefore, ceased to be "competitive" in Buenos Aires State, it can be observed a reduction of $24.2 \%$ in the number of farms. This occurred due to a reduction of small and medium-scale farmers associated with the concentration of land into farming units of more than 500 hectares; 2) annual losses in rural work rise 17.043.000 \$/year or US\$4.260.750 or, from another point of view, 4.128 tractor drivers, 3.926 mechanics and 4.600 farm workers, with an overall 12.000 rural workers; 3 ) increase of subsoil compaction and soil erosion was found due to high axle load of machinery equipment which also caused a decrease in crop yields ranging between $9 \%$ and $38 \%$ of the total yield per hectare of soybean crop, affecting the producers.
\end{abstract}

Keywords: Agricultural Sustainability, Small Producers, Agricultural Machinery, Rural Workers

\section{Introduction}

\subsection{Modernization Process}

In the Republic of Argentina, grain production is about 80.8 million Ton'year ${ }^{-1}$ with a value of US\$6.4 billion. Grain exportation is one of the pillars of the country's economy, as it provides US\$ 2.7 billon. In terms of climate, the Rolling Pampas region is characterized by intense periods of rainfall. These rains are particularly com- mon when summer crops have not completely covered the land or have yet to be sown. It is also identified by recurring seasonal drought during flowering and grain filling. This occurrence has a probability of about $70 \%$ [1].

In recent years the use of land for agricultural purposes has intensified overall. According to [2], an intense process of modernization was observed in the Pampas region of Argentina at the beginning of the 1970s. The use 
of machinery for farm work, the perfection of handling techniques, the incorporation of improved seeds, and the use of fertilizers and pesticides together influenced a significant increase in the productivity of land, manual labour and capital. This process of modernization was accompanied by technological practices oriented towards increasing productivity. For family-owned farms in the Pampas region this period represented a time of social restructuring and new investments. A great deal of disillusion arose among producers whose meagre previous crop yield did not allow them to access the new system. Many of them left farming but continued to maintain ownership of their land while others consolidated to form a significant segment of contractors. A study carried out in this region reveals that at the beginning of the 1980s $50 \%$ of the land in use in the area was leased to contractors by the owners.

Despite positive economic results this period of agricultural renewal also brought about consequences that proved to be detrimental to producers. By the end of the 1980s numerous sectors were in states of crisis. Some of the main effects caused by this agricultural development are:

- Exhaustion of resources, mainly soil, with serious erosion problems brought on by inappropriate land use.

- Loss of biodiversity in the ecosystem (contamination of tributaries and streams, decrease in the presence of important flora and fauna for sustainability).

- Relocation of ranching to more remote areas and the increase of land area dedicated to farming.

- Crisis among family-owned farms who cannot access to new improved technologies due to profitability, obsolete machinery, the impossibility of access to credit, etc.

- Emergence of new players on the agrarian sector: public limited companies or agricultural investment funds (based on short-term production criteria), contractors that displaced the old system of leasing, where it can be seen that access to capital becomes an important source of profitability against owning land.

- Increase in specialized production, which implies the subordination of farming production to the dynamic of capital.

- More direct relationships between the entities generating technology and the most important farm lands.

One very common observation of many Latin American authors is that the process of agrarian capitalization has caused an increase in temporary workers and a decrease in permanent ones [3-5].

[6] Adduces that $50 \%$ of the rural workers in Argentina are not legally registered. This group suffers from an enormous lack of protection and greater vulnerability than rural workers with contracts. In comparison with other economic sectors, illegal labour is excluded due to stricter labour contract laws, which are enforced by a "special statute" that protects workers to a small extent.

According to the definition by the Rural Workers Organizations "Convention of the International Labour Organization", a rural worker is understood as: any person engaged in agriculture, handicrafts or a related occupation in a rural area, whether as a wage earner or, tenant, sharecropper or small owner-occupier who work the land themselves, with the help only of their family or with the help of occasional outside labour and who do not a) permanently employ workers; b) employ a substantial number of seasonal workers; or c) have any land cultivated by sharecroppers or tenants" [7].

These technological transformations that took place in Argentina can be extrapolated to Latin America. According to most authors these transformations have had a significant impact on the labour market, thereby changing the composition of the agricultural work force.

According to [5], this can be observed in at least four basic aspects, namely:

a) The replacement of resident workers with external wage-earning workers;

b) In terms of wage-earning work, the rise in temporary and seasonal work;

c) The increased incorporation of women into the agricultural work force;

d) Rural workers moving to urban centers.

From this period of modernization emerges direct sowing (DS) or no-tillage systems as an answer to the crisis that affects farming production in this region. On one hand DS is defined as one that overcomes the degradation processes that had affected resources, mainly land, which in specific areas had reached alarming degrees of erosion. DS was introduced as one which surpassed those that had been prevailing since the Green Revolution, characterized by the incorporation of technologies of inputs and machinery. DS represents a technological leap in qualitative terms as it builds on the Green Revolution system by technologically changing processes. The changes obtain significant increases, particularly in the processes of production and work. Therefore, it is possible to identify this system as the core of the radical transformation in the farming production sector [8].

In the 1980s, DS began to spread in a sustainable fashion as a response to rising availability and cost reduction of agrochemicals. Another factor was the simplification of labour, as it implied a decrease in both the number of operations and the need for machinery. This system of work, which currently covers 20 million hec- 
tares in Argentina forms part of a technological practices comprised of an enormous amount of imported machinery, Monsanto herbicides and transgenic soybean [9-11].

According to [12], in an extensive study conducted in the town of Zavalla (province of Santa Fe, Argentina), the majority of producers view DS and its variety of transgenic seeds as not just simply other techniques in the technological practice spread throughout the farming world of the Pampas in recent years.

Instead, it is seen as part of a complete productive strategy which withstands the risk of impoverishment and/or exclusion as a result of the implementation of global new-liberal policies. This threat requires new solutions that allow farm units to endure. These answers can be found by both learning from past experience and by incorporating new innovations.

\subsection{Rural Development}

The first step in analyzing rural development consists of identifying the theoretical background behind development plans that requires strengthening. The objective of this process is always stated to be that of improving the standard of living of the population in a given area through decentralization, local participation and encouraging endogenous resource usage. However, in reality, the theoretical framework from which development emerges is the ultimately determines the extent of said development.

The solution in the eyes of institutionalized international organizations and multilateral development banks lies in the process of economic globalization. This process offers the masses of the periphery the same general level of consumption as the city. The Periphery, whose population is rapidly multiplying, can achieve this level through the "indispensable economic growth" required by modern societies.

The approach behind the official method for achieving sustainable development seeks to strengthen economic growth in those areas where basic needs are not satisfied. At the same time, it respects "growth in other areas, provided they fulfill the requirements of sustainability and reject the exploitation of others", in a way that ensures "equal opportunities among all people".

Sustainable development has its origins in the preparation for the Stockholm Conference of 1972 and the work of the Club of Rome in the early seventies. These two events represented the first warnings against the environmental problems perceived at that time; the Global 2000 Report of 1980, which diagnosed the "state of the world" and the methodical approach to face the ecological crisis. This approach was part of the Bruntland Report which officially defined sustainable development.
Finally, the Earth Rio Summit set out the institutional strategy for sustainable development.

From the perspective of Agro-ecology, according to [13], a new paradigm of sustainability is required. It has to be ecologically friendly, economically viable, socially fair, culturally flexible as well as socio-culturally humanized. Constructing a development model that meets these demands implies that "as opposed to interdependence and concentration, dominant trends would have to be those of autonomy and decentralization, where local power prevails with all of the diversity that distinguishes it from what is global and homogeneous". Or, in other words, it would imply an autonomous development system based on local resources that will depend on the communal organisms of each territory, and it would oppose, therefore, the current trends of concentration of political and economic power. A model such as this one would be labour intensive rather than capital intensive.

However, all of these changes which have affected rural families and the environment have not appeared to have achieved improvements in the standard of living of wage earners and their families. Instead, they appear to have allowed poverty to accompany modernization. In more direct terms, the productive readjustment caused by modernization and industrialization has not resolved the old problems linked to agriculture-poverty has not diminished and land has come into the hands of a small number of owners, which has brought about the eviction of farming families and made wage earners the largest and poorest group in the farming world.

Finally: a widespread idea in some production circles of Argentina is that productivity increases when DS practices are adopted. Conversely, others suppose that negative effects caused by this practices on soil physical properties, crop yields, environmental and annual work cycles changing the relationship between employers and employees.

\section{Objective}

The objective of this paper was to carry out a study that would provide information on the effects had on the various parties in the agricultural sector and the environment as a result of adopting the technological practices (farming technique, machinery, agrochemicals and seeds) associated with the DS of soybean crops in Argentina.

\section{Study Hypothesis}

a) The mass adoption of technological practices by farmers of different social classes has intensified the inequality that already existed among them.

b) The transformations caused by new technologies are 
detrimental to urban and rural environments as they have negative consequences that do not coincide with the sustainable rural development model that this technology intends to defend.

\section{Methodology and Design}

Research was divided into three main parts:

a) Research of the background surrounding the topic of technology adoption in the Argentine farming world, especially in relation to DS and its impact on the labour market as well as on the environment in the core region of soybean farming.

b) Discussion of the nature of the theoretical and operational limitations identified and the development of complementary conceptual constructions.

c) Conducting interviews with producers, agrarian science professionals in contact with this topic, technical advisors, input suppliers, researchers studying the topic of rural labour, official agricultural engineers who conduct activities directly related to the technology herein studied and that work in the core soybean farming region in Argentina. It is hoped that this information provides an inter-subjective view of the problems, which in turn offers an interdisciplinary view of the topic as well as significant qualitative conclusions.

d) Field experiments in the core region of soybean farming studied soil compaction produced by DS machines traffic (tractors and planters). The region of soybean farming utilizing DS in Argentina is understood to be that region located between $24^{\circ} 45^{\prime}$ to $37^{\circ} 55^{\prime}$ south latitude and $64^{\circ} 01^{\prime}$ to $58^{\circ} 31^{\prime}$ west longitudes (Figure 1). Statistical analyses were performed utilizing the Statgraf program 7.1. An analysis of variance (ANOVA) was carried out on the data and Duncan's multiple range test was used to analyze the means.

\section{Results and Discussion}

The following paragraphs will discuss the nature of the theoretical and operational limitations that arise when adopting the complete technological practice: DS, application of Glyphosate and the utilization of genetics modified organisms (GMOs) varieties.

\subsection{Impact of adoption: Environmental and Human}

In Argentina although the practice for DS is defended by its promoters as an example of sustainability and development superior to the traditional model of agricultural development presented by the Green Revolution. Nevertheless, problems begin to be identified associated with the utilization of glyphosate and transgenic seeds only several years after its adoption, in addition to the effects

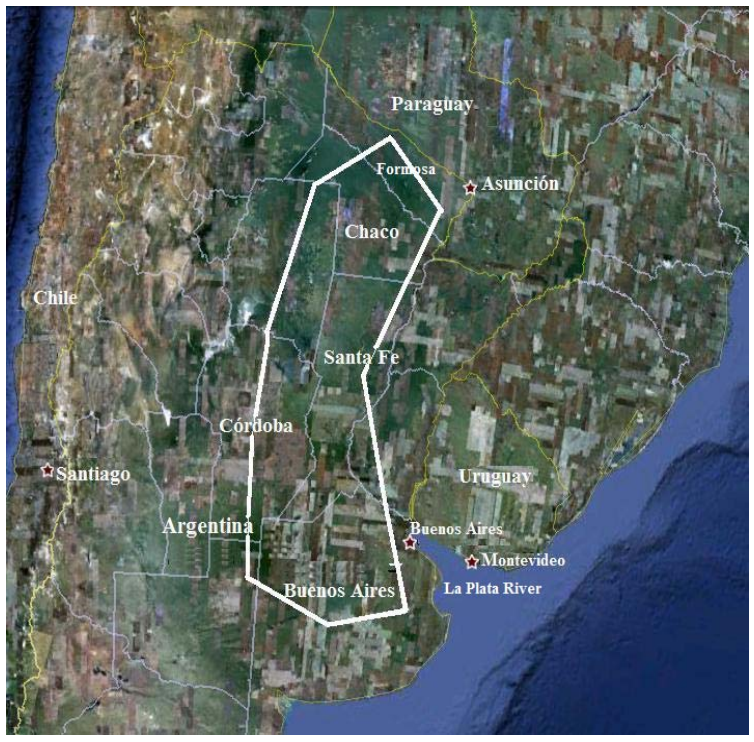

Figure 1. Core region of soybean farming under DS system.

on producers and rural communities cited in the following paragraph.

There is proven evidence of the risks that permanent and systematic application of Glyphosate can have to human health and the environment. Glyphosate is a broadspectrum herbicide used to kill crop weeds. It is used on a wide variety of annual, biennial and perennial grasses, broad-leafed weeds and woody shrubs. Unintentional chemical drift of this product can affect trees and bushes located near crops. Most products that contain glyphosate are made or combined with a surfactant (known as POEA) which helps the glyphosate to penetrate plant tissues. This gives the commercial formula toxicological characteristics dissimilar from those of glyphosate alone. It has been determined that the surfactant in Roundup is the main cause of the formula's toxicity. POEA, whose acute toxicity is three times greater than that of glyphosate, causes gastrointestinal pain, damage to the central nervous system, respiratory problems and the destruction of red blood cells in humans. In addition, it is contaminated with 1,4-dioxin, which has caused cancer in animals and liver and kidney damage in humans [14].

One incident that affected a large number of small producers involved sprayings with Roundup glyphosate. The sprayings, conducted by agricultural company in Formosa state, destroyed 23 plantations (yams, bananas, beans, cassava, pumpkins, corn, citrus, cotton, etc.) owned by families of small landowners and small farmers that formed the "Civil Association of Pirané". In this particular case, following frequent use of agro-toxins, "the deaths of a large number of farm poultry and other domestic animals were documented, along with some equine that inhabitants 
utilize to perform farm labour". At the same time, several media sources reported a great loss of life among fish and poultry in the neighboring towns of El Colorado and General Belgano [15].

The events unfolded as follows: in early 2003 the small producers in Colonia Sené (Formosa state) reported that the herbicides large companies utilized in DS were killing their crops and poisoning their children. Colonia Sené is a town of small agricultural producers, owners of plots no larger than ten hectares. On their land their grow corn, yams, pumpkins, melons and beans for family consumption and they sell the surplus at an open market organized every Saturday in the main square of the nearby town of Pirané. They also plant cotton, albeit on a smaller scale, as it is a crop that previously demonstrated positive results. On February $2^{\text {nd }}$, on the farms of Colonia Loma Sené, a small town of Formosa state, all the crops were found scorched. A company had been spraying the day before on the adjoining fields of soybean crops. The wind blew northward, which scattered the spraying liquid in a mist over several nearby hectares. Two inhabitants, Eugenia Giménez and Cándida Fernández, remember the vapors in the air immediately irritated their eyes. "Afterwards some of us had nosebleeds, others suffered from respiratory tract problems and hives". The crops dried up, "the leaves on the red peppers shriveled up and shrank like curly hairs. The looked like plastic. The cassavas were lost, and the melons looked like someone had poured hot water on them. The smallest farm animals, like the hens, died.

The producers denounced that these effects were the result of an herbicide mixture utilized in DS of transgenic soybean. They now demand responsibility for the damages caused and for environmental studies to be conducted considering they do not know what consequences they may suffer from the contamination. Subsequently, they obtained the ruling of El Colorado civil court judge, Silvia Amanda Sevilla, who ordered an immediate halt to sprayings with glyphosate in Colonia Loma Senés, $20 \mathrm{~km}$. from Ciudad de Pirané. In the same colony there are some very large farms covering thirty hectares on average that in recent years have been leased to outside companies dedicated to soybean farming with the DS method. This fact, along with the mere proximity of these fields to the small farms, which in many cases are only separated by roads or wire fencing, and the utilization of herbicides by outside companies generate serious damages on the plantations of the local inhabitants".

As regards the utilization of transgenic seeds of soybean varieties, Argentina experienced an incredibly fast adoption of transgenic soybean. This process began in $1996 / 1997$, with $0.6 \%$ of land area sown with soybean compared to $2000 / 2001$ when the percentage was $90 \%$. The ideal rotation for the core region in terms of fertility should be one year soybean, one year corn. At present, in general, producers practise three years soybean, one year corn. Due to the settling of nitrogen produced by the soybean, the corn that follows it in rotation has greater yield. However, it is not farmed for strictly economic reasons as it is not as profitable a crop as soybean. Producers attempted to farm butterfly corn as it has a higher market value. In any case, there was quite a lot of doubt surrounding GMOs. [16] Cite that many scientists explain that the ingestion genetically engineered foods is not harmful. However, recent tests demonstrate that potential risks exist from eating such foods. This is because the new proteins produced by these foods can: act as toxins and alter the metabolism of the plant that produces the food, which induces the latter to produce new allergens or reduce its quality. This fact was verified with herbicide resistant soybean seeds. The seeds contain less isoflavones, an important phytoestrogen that protects women from a high number of cancers.

Up until not recently agrarian diversity had always been increasing. However, in industrialized countries, plant and animal genetic engineers, trading houses and governments themselves combined forces to supply new varieties and uniform breeds that would replace the tremendous heterogeneity already existing.

This process of combining forces began at the end of the eighteenth century. At the beginning of the twentieth century the richest farming areas (i.e., best soils, favourable orography, water supply) of Europe and the USA were sown with varieties that had been obtained or selected by professional plant breeders. The reduction of genetic variety, however, has led to numerous disasters in the world (Table 1).

Table 1. Reduction of genetic variety: effects on farming areas.

\begin{tabular}{ll}
\hline \multicolumn{1}{c}{ EFFECTS } & CAUSES \\
\hline $\begin{array}{l}\text { Between years 1840-1850 more than two } \\
\text { million Irishmen died from hunger }\end{array}$ & $\begin{array}{l}\text { Smut attack in } \\
\text { potatoes }\end{array}$ \\
$\begin{array}{l}\text { In USA in 1970 there were big losses of } \\
\text { corn (in some states }>50 \%) .\end{array}$ & Fungi Diseases \\
$\begin{array}{l}\text { In Cuba in 1980 there were big losses of } \\
\text { sugar cane (more than a million Tons). }\end{array}$ & Rust attack \\
$\begin{array}{l}\text { In 1943 in Bengala there was a great famine } \\
\text { when getting lost good part of the rice. }\end{array}$ & $\begin{array}{l}\text { Diseases "it stains } \\
\text { brown" }\end{array}$ \\
\hline
\end{tabular}


There is currently talked of a new revolution, the socalled biotechnology. This consists of genetic manipulation at a molecular level in order to obtain products (i.e., seeds, plants, embryos) that, apart from their secondary characteristics, produce substantial profits for trading houses. However, there are also numerous results that can be considered disadvantages, such as higher crop yields, substitution of natural raw materials (i.e., cocoa, sugar, vanilla) for cheaper ones, and greater resistance in conservation. These changes, achieved through the implantation of genetic material in a living organism that bypasses evolutionary barriers, which species took thousands of years to create, may result in serious and unimaginable consequences for public health, the environment, and the overall agricultural system (Table 2).

It is worth adding that the degree of genetic uniformity present in the agricultural sector is tremendous. For example, there are six corn hybrids alone that account for $70 \%$ of this crop's production worldwide [17]. This also occurs in the world of stockbreeding, where just one breed, Friesian, currently constitutes $60 \%$ of dairy cattle in the European Union [18].

\subsubsection{Impact on Agricultural Soil}

In North America during the 1980s, the standard tractor sold increased from $200 \mathrm{~kW}$ to $300 \mathrm{~kW}$ and the largest tractors available increased from 300 to $500 \mathrm{~kW}$. The Argentine market followed a similar trend where standard cereal farming tractors offered $90 \mathrm{~kW}$ and an available range of greater power reaching $260 \mathrm{~kW} \mathrm{[10].}$

These trends have indeed led to development. For example, where industrial grain combines before had boasted more than a $16 \mathrm{Mg}$ load on the front axle, newer ones, weighing in the area of $20 \mathrm{Mg}$, coupled with a single-axle header trailer were capable of transporting 35.3

Table 2. Biotechnology: potentials impact.

The DNA can escape towards wild related plants, creating plants of difficult control (major competitiveness on having had resistance to herbicides, tolerance to the water stress ...)

The local varieties would be replaced by more uniform varieties. This produces a change from the liberation of varieties genetically modified varieties.

The genetically modified plants present the potential danger of producing toxic secondary proteins.

The genetic modification can concern the host organism in his aptitude to use substrates as the nitrogen or the lignin, turning it in pathogenic and to alter the balance between the same one and the ecologically related populations.
$\mathrm{Mg}$ of grain. The consequence of operating at these axle weight-load levels is that producers run the risk of excessive compaction of farming soil; this affects root growth, crop yield, and the quality of the agro-ecosystem. Compaction is not only superficial, but can also be under de surface, being sub-superficial, which is more expensive to solve.

This occurs regardless of whether a machine possesses sufficient vehicle size or is equipped with any other highflotation mechanism allowing it to operate with low surface pressure in the area of tire/soil contact [10,11,19-21]. Soil is compacted when the proportion of total volume of pores occupied by air in relation to soil does not permit maximum crop growth. [1] Demonstrated that with the farming methods in the Las Pampas region, due to the traffic of machinery during harvesting, a loss to the producer occurs that ranges between $9 \%$ and $38 \%$ of the total yield per hectare of soybean crop (Table 3).

As previously stated, these extreme weights cause soil compaction problems. Once soil is compacted, the solution of deep tillage is then employed. This process, which is also very expensive, provided questionable results [12,22].

Deep soil tillage below normal plowing depth is problematic. The solution to this problem, or at least the method of combating it, is always extremely expensive. In general, the process is complicated in technical terms due to strong demands for more powerful, and less common, farming equipment. It is sometimes impossible to solve this problem in economically viable terms [20]. The bulk density and penetration resistance of soil are the most commonly used indicators for determining soil compaction. Both are sensitive to the effect of vehicles with heavy axle weight-loads, similar, for example, to what DS machinery weigh. Table 3 displays the changes that occurred in soil bulk density depending on the vehicles utilized. This soil parameter in the control area, with no vehicle transit, registered high values in all profile categories. On the superficial level, it surpassed the value of $1.2 \mathrm{Mg} \cdot \mathrm{m}^{3}$, indicated by [23] as the value necessary to

Table 3. Bulk density values $\left(\mathrm{Mg} / \mathrm{m}^{3}\right)$ and soybean yields for three traffic intensities (Pergamino county Argentina).

\begin{tabular}{ccccc}
\hline $\begin{array}{c}\text { Traffic intensities } \\
\text { (passes) }\end{array}$ & 6 & 8 & 10 & Control plot \\
\hline $\begin{array}{c}\text { Soybean yields } \\
(\mathrm{Mg} / \text { hectare })\end{array}$ & $2.8 \mathrm{a}$ & $2.4 \mathrm{~b}$ & $1.9 \mathrm{c}$ & $3.1 \mathrm{a}$ \\
Depth range (mm) & \multicolumn{5}{c}{ Bulk density values $\left(\mathrm{Mg} / \mathrm{m}^{3}\right)$} \\
$0-150$ & $1.38 \mathrm{a}$ & $1.40 \mathrm{a}$ & $1.51 \mathrm{~b}$ & $1.33 \mathrm{a}$ \\
$150-300$ & $1.60 \mathrm{a}$ & $1.65 \mathrm{a}$ & $1.60 \mathrm{~b}$ & $1.59 \mathrm{a}$ \\
$300-450$ & $1.88 \mathrm{a}$ & $1.90 \mathrm{a}$ & $1.97 \mathrm{~b}$ & $1.87 \mathrm{a}$ \\
\hline
\end{tabular}

Values with different letters (vertically) show significant differences among treatments $(P<0.01$ Duncan's Multiple range test). 
achieve more rapid and complete emergence of wheat crops. Below the surface, values were also found that surpassed the critical levels of $1.46 \mathrm{Mg} \cdot \mathrm{m}^{-3}$, cited by [24] for root gramineae development, and $1.6 \mathrm{Mg} \cdot \mathrm{m}^{3}$, which is established as the radical growth threshold according to [25]. In general, all the other treatments increased the soil bulk density, in all soil profiles, with respect to the control area, but only the area passed over 10 times obtained statistically significant differences. When the tractor passes 10 times, the soil bulk density increased $6.9 \%$ and $5.4 \%$ in the strata of 150 to $300 \mathrm{~mm}$ and 300 to 600 $\mathrm{mm}$, respectively. In relation to this parameter, unlike the conclusions of [26], 10 passes was found to be the critical number at which a low axle weight-load can replace the weight factor in terms of responsibility for subsoil compaction.

According to what has been stated it can be inferred that the DS system reveals a high degree of consolidation and/or compaction, natural or induced, which compromises the introduction and development of crops. Crop yield was also affected by repetitive transit. In the same tire track, yield was different depending on the degree of intensity applied. Also, Table 3 reveals that as traffic intensity increased, soybean crop yield decreased.

\subsubsection{Social Impact}

\subsubsection{In General}

As the previous paragraph states, there are several social and economic consequences of the "biotechnology revolution." Some of these are the loss of buying power among farmers who depend on external inputs that are increasingly more expensive (while the price of produce rose to a lesser degree and even fell), the deterioration of diet among the inhabitants of nearby countries (with the consequential rise in illnesses and death), and the loss of homes among poor rural families (as many mortgaged their property amidst highly dependent and unstable production) [27]. This all combines to paint a very dark picture: according to the Food and Agriculture Organisation there are close to a billion malnourished people in the world [28].

The adoption of this technological practice not only modified the production relationships of individual farming units, but it also affected the economic and social spheres of rural communities. Also, it did not take long to drastically transform the landscape, consequently installing a system of farming without farmers.

The extensive network of machinery contractors and farming equipment parts salespeople, as well as local input distributors and all of the cultural and social life that accompanied small agro-industry disappeared leaving immense vacant territories. The effects of this pro- gressive loss of culture and deep-rooted community life consequently have a direct impact on political and social life in the rest of Argentina. There are currently 500 towns registered as abandoned or en route to disappearing. This could possibly equate to the highest proportion in the world experiencing the phenomenon of emigration to poor urban areas. According to [29], there are currently an approximate 300 thousand registered evicted producers and more than 13 million hectares that have been seized due to unpayable mortgage debts. This crisis has been so serious that recent statistical data reveal that in the last decade the deterioration of family farming, marked by the disappearance of a high percentage of farms, has been even higher than in the grain growing regions of more advanced capitalist countries such as the United States [30]. In the town of Marcos Juárez, for example, considered the cradle of DS, the National Agricultural Technology Institute concludes that the deterioration of family income from farms (retail buying power) reached $41 \%$ per hectare comparing the average values of the 1990s to the 1980s. Farms smaller than 190 hectares, therefore, ceased to be "competitive". As for the town of Pergamino, one that can be used as an indicator of the massive adoption of DS, there was a $24.2 \%$ reduction in the number of farms. This occurred at the expense of small and medium-scale farmers and is associated with the consolidation of land into farming units of more than 500 hectares (Table 4).

Table 4. Quantity and surface of the farms, according to scale of extension, and variations 1988-1999.

\begin{tabular}{ccccc}
\hline $\begin{array}{c}\text { Extension scale } \\
\text { (hectares) }\end{array}$ & $\begin{array}{c}\text { Year } \\
1988\end{array}$ & $\begin{array}{c}\text { Year } \\
1999\end{array}$ & Variation & $\begin{array}{c}\text { Surface } \\
(\%)\end{array}$ \\
\hline Up to 5 & 50 & 31 & -38.0 & -44.0 \\
$5.1-10$ & 59 & 33 & -44.1 & -45.4 \\
$10.1-25$ & 150 & 89 & -40.7 & -42.7 \\
$25.1-50$ & 277 & 195 & -29.6 & -28.9 \\
$50.1-100$ & 343 & 242 & -29.4 & -29.1 \\
$100.1-200$ & 330 & 250 & -24.2 & -23.6 \\
$200.1-500$ & 289 & 245 & -15.2 & -11.8 \\
$500.1-1000$ & 71 & 84 & 18.3 & 19.1 \\
$1000.1-2500$ & 31 & 43 & 38.7 & 42.4 \\
Más de 2500 & 5 & 5 & 0 & 3.8 \\
Total & 1605 & 1217 & -24.2 & -1.9 \\
\hline
\end{tabular}

Source: Martinez Dougnac, 2001, Agricultural Experimental Census 1988 and 1999. 
This analysis coinciding with [31] proceeds to reveal that DS of soybean during the 1990s experienced sustainable growth. However, the emergence of transgenic seeds resistant to glyphosate proved to be a turning point after which the adoption of this technique became more widespread among producers. This can be seen in Table 5.

Finally in this point: the combination of DS and transgenic seeds represents a qualitative change in terms of the technological model because of its impact on the kind of fixed capital and labour organization necessary for continuing with the production process. Obviously, this concentration process cannot be attributed solely to DS. It is also associated with the phenomena of falling profitability, lack of financing, the burden of financial debt accumulated over years, slow undercapitalization, price instability, etc. However, the aforementioned change to the implementation system and the direction of crops which emerges with the generalization of DS directly affects labour organization on farms and indirectly affects demand for manual labour in communities.

\subsubsection{On Small Producers and Rural Workers}

In order to address small producers this study utilizes the concept created by [32]. They define rural people or small producers as those socioeconomic agents whose agricultural production units-domestic under any holding status-produce for sale at market in conditions of scarce natural resources (land and/or water, in quantity or quality) and/or capital, and where labour is primarily familiar. The result of the combination of these factors is the absence of long-term economic profits, which prevents capitalization of the production unit as well as access to optimum living conditions for the family unit that depends on it.

According to the last agrarian census, between 1991 and 2001, around 150,000 small producers disappeared. This change led to the most immense concentration of large estate owners in the history of Argentina: 6200 owners held $49.6 \%$ of all farm land in the nation, and accompanying this process of concentration and production manipulation by multinational companies, $160,000,000$ hectares belong to foreign owners. On top of this it is necessary to add the utilization of a large technological practice-machinery, seeds, and chemical products all of which is unattainable for the majority of small producers.

During the period of modernization, technological change meant a reduction in manual labour among families. The members of these families found work in other sectors of the economy. This situation changed in the second half of the 1990s when there was no longer a thriving labour market. As a result, many people who had emigrated from the agricultural sector did not have jobs anymore. For example, if we consider that a DS planter has a useful life of 12,000 hours or 15 years, this machine should be use for at least 800 hours per year. Also considering that for conventional tillage works four employees are needed (tractor driver, mechanic and two farm workers) and for seeding with the DS system you only need two: tractor driver and mechanic.

According to [33] the difference between wages from both systems is of 7410 \$/year (1852 US\$/year). Taking in account the planter equalization point ( 800 hours/year) DS equipment should be used over this point, and also considering a mean work rate of 5 hectares/hour this equipment works over 4000 hectares/year. With approximately 9,200,000 hectares worked under DS system, annual losses rise, in the rural sector, 17,043,000 \$/year $(4,260,750$ US\$/year). This means, according to [10], 4128 tractor drivers, 3926 mechanics and 4600 farm workers, with an overall 12,000 rural workers.

Table 5. Historical sequence: land use and technological practice in the region under study.

\begin{tabular}{llll}
\hline \multicolumn{1}{c}{ Years } & \multicolumn{1}{c}{$\begin{array}{c}\text { Between } \\
1970-1980\end{array}$} & \multicolumn{1}{c}{$\begin{array}{c}\text { Between } \\
1980-1990\end{array}$} & \multicolumn{1}{c}{$\begin{array}{c}\text { From 1990 } \\
\text { up to today }\end{array}$} \\
\hline Crop rotation & Wheat Soybean & Wheat Soybean & Wheat, Soybean and Corn \\
Tillage systems & $\begin{array}{l}\text { Conventional tillage system } \\
\text { with moldboard plough }\end{array}$ & $\begin{array}{l}\text { Chisel plough and minimum } \\
\text { tillage with light disk harrow }\end{array}$ & Direct sowing \\
Direct sowing & It is not realized & Only soybean & Partially in soybean, wheat and maize \\
Rotation agriculture and ranching & Only in some establishments & $\begin{array}{l}\text { Almost disappearance of the cattle } \\
\text { system. }\end{array}$ & $\begin{array}{l}\text { Location of the ranching in marginal } \\
\text { sectors }\end{array}$ \\
Types of herbicide & Generic of low spectrum & Specific, varied & Glyphosate \\
Fertilizers & Nitrogenous & Maize. Nitrogenous & Nitrogenous Phosphorus \\
Seeds & Hybrids and varieties & Hybrids and varieties & GMOs \\
\hline
\end{tabular}

Source: Cloquell et al., 2000, South of Santa Fe state. 
In this hand, [33] consider that the $\$ 17,043,000$ $(4,260,750 \mathrm{US} \$ /$ year $)$ is lost from the system as they are not reinvested in the system itself. Also, tractor operators, mechanics and labourers are not hired by machinery or agrochemical factories.

The relocation of the rural worker to the urban centre is a contradictory reality that emerges from increasing rural depopulation and the growing need for a seasonal work force in rural areas.

In the past it was common to see and talk about "illegal settlements" in big cities. Today, however, it is common to observe this in small towns and villages, where access to basic services and infrastructure is scarce due to the extreme poverty predominant in these areas. It is seen that the magnitude of these transformations not only concerns rural areas but has markedly begun to shape a new urban reality as well, at least for most countries. For this reason, carrying out a strict division between urban and rural problems weakens the analysis of these types of trends.

The effect that recent transformations in the farming world have had on the "world of rural labour" will now be directly observed. These changes that have been brought on by modernization of production processes, expansion of agro-industrial complexes and the continued growth of the urban work force have all merged and modified the characteristics of rural employment. The job market, traditionally the setting for interaction between labour supply and demand, has been altered by these transformations.

The overall complexity of the widely-used technological practice that this paper deals with is explained by the continuous outsourcing of needs not met on the production unit itself, generating a more pronounced division of labour. Greater dependence on external inputs drives producers to require technical advising in order that the system may function correctly. Moreover, regarding manual labour requirements, it is important to note the decreased demand for machine operators (without a decrease in labour intensity) and the increased demand for higher qualified personnel.

This study considers that the technological spreading of DS as a successful example of a supposed new paradigm of sustainable development is nothing more than a corrected version of the modernization theory based on agrarian capitalism with an industrial background, within the framework of the environmental paradigm. For reasons like these, sustainable development has become the centre of attention in response to pressure from ecological movements and strong social awareness of the biosphere's deterioration.

Having finished this discussion, it is worthwhile to re- iterate the ideas of [13] who state that "a new paradigm of sustainability is required. It must be ecologically friendly, economically viable, socially fair, culturally flexible as well as socio-culturally humanized." As has been demonstrated up until this point, it is clear that the principles of sustainability discourse do not stand firm in practice. It can therefore be inferred from the bibliography compiled as well as this study that there is sufficient evidence to validate hypotheses 1 and 2 .

\section{Conclusions}

Crops that are resistant to herbicides intensify and increase dependence on the use of these same crops in farming, which causes an increase in adverse environmental effects on soils and waters and repercussions on human health. At the same time, high axle load on machinery, which is utilized in the DS technological practice in order to increase the work capacity of equipment, is causing severe soil compaction which is leading to a situation that, due to costs, will be difficult to solve.

By means of development of technologies and the increase in capital dedicated to agricultural production, work productivity has been increased. Annual work cycles have been altered causing a rise in temporary job positions and a reduction in permanent job positions. This in turn modifies relationships between those offering jobs and those looking for jobs.

However, all of these changes which have affected rural families and the environment have not appeared to have achieved improvements in the standard of living of wage earners and their families. On the contrary, they appear to have allowed poverty to accompany modernization. In more direct terms, the productive readjustment caused by modernization and industrialization has not resolved the old problems linked to agriculture: poverty has not diminished and land has come into the hands of a small number of owners, which has brought about the eviction of farming families and made wage earners the largest and poorest group in the farming world.

The State should implement strategies that focus on the most vulnerable sector-agriculture-which affects so many people. The objective of these strategies should be that of breaking continued poverty, making a sector that is competitive internationally just as successful internally. On one hand, a sector exists that provides high dividends to national and international companies that operate in the area. However, on the other hand, a great number of people suffer chronic poverty than surpasses the national average. It is a paradox that could be avoided through social policies, reserved for this group of rural workers, seeking to reduce the high rate of poverty and the number of unfulfilled basic needs. 


\section{REFERENCES}

[1] G. F. Botta, O. Pozzolo, M. Bomben, H. Rosatto, D. Rivero, J. M. Ressia, M. Tourn, E. Soza and J. M. Vázquez. "Traffic Alternatives in Harvest of Soybean (Glycine max L.): Effect on Yields and Soil under Direct Sowing System," Soil and Tillage Research, Vol. 96, No. 1-2, 2007, pp. 145-154. doi:10.1016/j.still.2007.05.003

[2] E. Obschatko, "Technological Change Stages," In: O. Barsky, Ed., FCE/IICA/CISEA, Buenos Aires, 1988, p. 110.

[3] M. Murmis, "Small Farms Typology in America," Wolf y Otros, Centro Editor de América Latina, Buenos Aires, 1992, p. 156.

[4] S. E. Gómez, "The Agrarian Poor. The Temporal Worker," FLACSO, Santiago de Chile, 1993, p. 140.

[5] C. Kay, "Globalization, Peasant Agriculture and Reconversion," Bulletin of Latin American Research, Vol. 16, No. 1, 1997, p. 130.

[6] M. Bendini, "La Globalización y los Trabajadores Agrarios en Argentina. Nuevos y Viejos Actores," Proceeding of the 21st Latin-American Rural Sociology Congress, San Pablo, 21-23 April 1997, pp. 160-181.

[7] C. Van Dam C. "Ocupación, Degradación Ambiental, Cambio Tecnológico y Desarrollo Sostenible: Los Efectos de la Introducción del Paquete Soja/Siembra Directa en el Chaco Salteño," Tesis de Maestría en Gestión Ambiental y Desarrollo, Centro Bartolomé de las Casas, Colegio Andino, Escuela Andina de Postgrado, Salta Argentina, FLACSO, 2002.

[8] M. Blanco, "The Conservationist Agriculture and Their Effects on the Rural Manpower: The Application of Direct Sowing on Cereals and Oleaginous Crops," In: G. Neiman, Ed., Field Work, Centro de Integración, Comunicación, Cultura y Sociedad (CICCUS), Buenos Aires, pp. 134-152.

[9] G. F. Botta, D. Jorajuria and L. Draghi, "Influence of the Axle Load, Tyre Size and Configuration, on the Compaction of a Freshly Tilled Clayey Soil," Journal of Terramechanics, Vol. 39, No. 1, 2002, pp. 47-54. doi:10.1016/S0022-4898(02)00003-4

[10] G. F. Botta, D. Jorajuria, R. Balbuena and H. Rosatto. "Mechanical and Cropping Behaviour of Direct Drilled Soil under Different Traffic Intensities: Effect on Soybean (Glycine max L.) Yields," Soil and Tillage Research, Vol. 78, No. 1, 2004, pp. 53-58. doi:10.1016/j.still.2004.01.004

[11] G. F. Botta, A. Tolón-Becerra, X. Lastra-Bravo and M. Tourn, "Tillage and Traffic Effects (Planters and Tractors) on Soil Compaction and Soybean (Glycine max L.) Yields in Argentinean Pampas," Soil and Tillage Research, Vol. 110, No. 1, 2010, pp. 167-174. doi:10.1016/j.still.2010.07.001

[12] S. Rosenstein, C. Primolini, A. Pasquale and G. Giubileo. "Las Redes de Diálogo y la Transformación del Sistema de Conocimiento Local," Revista de Investigaciones de la Facultad de Ciencias Agrarias, Vol. 5, No. 1, 2004, pp. 43-62.
[13] E. Sevilla Guzmán, "Redescubriendo a Chayanov: Hacia un Neopopulismo Ecológico," Agricultura y Sociedad, Vol. 55, April-June 1990, pp. 201-249.

[14] E. Goldsmith and Z. Goldsmith, "The Monsanto Files," The Ecologist, Vol. 28, No. 5, 1998, p. 19.

[15] News Paper La Mañana, 5th March 2003, Formosa State, Argentina.

[16] M. Altieri, "The Ecological Role of Biodiversity in Agroecosystems," Agriculture Ecosystems \& Environment, Vol. 74, No. 1-3, 1999, pp. 19-31. doi:10.1016/S0167-8809(99)00028-6

[17] S. Gliessman, "Understanding the Basis for Sustainability of Agriculture in the Tropics: Experiences in Latin America," In: C. A. Edwards, et al., Eds., Sustainable Agricultural Systems, Soil \& Water Cons, Soc., Ankeny, 1990, pp. 378-390.

[18] Food and Agriculture Organization, "AWorld Agriculture: towards 2010-FAO," In: N. Alexandratos, Ed., Roma, FAO y Ediciones Mundi-Prensa, Madrid, pp 230.

[19] G. F. Botta, D. Jorajuria, H, Rosatto and C. A. Ferrero. "Light Tractor Frequency on Soil Compaction in the Rolling Pampa Region of Argentina," Soil and Tillage Research, Vol. 86, No. 1, 2006, pp. 19-14. doi:10.1016/j.still.2005.01.014

[20] G. F. Botta, D. Rivero, M. Tourn, F. Bellora Melcom, O. Pozzolo, G. Nardon, H. Balbuena, A. Tolón-Becera, H. Rosatto and S. Stadler, "Soil Compaction Produced by Tractor with Radial and Cross-Ply Tyres in Two Tillage Regimes," Soil and Tillage Research, Vol. 101, No. 1-2, 2008, pp. 44-51. doi:10.1016/j.still.2008.06.001

[21] G. F. Botta, A. Tolón-Becerra and F. Bellora Tourn. "Effect of the Number of Tractor Passes on Soil Rut Depth and Compaction in Two Tillage Regimes," Soil and Tillage Research, Vol. 103, No. 2, 2009, pp. 381-386. doi:10.1016/j.still.2008.12.002

[22] G. F. Botta, D. Jorajuria, R. Balbuena, M. Ressia, H. Rosatto and M. Tourn, "Deep Tillage and Traffic Effect on Subsoil Compaction and Sunflower Yields," Soil and Tillage Research, Vol. 91, No. 1-2, 2006, pp. 164-172. doi:10.1016/j.still.2005.12.011

[23] H. Nasr and F. Seles, "Seedling Emergence as Influenced by Aggregate Size, Bukk Density, and Penetration Resistance of the Seedbed," Soil and Tillage Research, Vol. 34, No. 1, 1995, pp. 61-76. doi:10.1016/0167-1987(94)00451-J

[24] F. J. Veihmeyer and H. Hendrickson, "Soil Moisture in Relation to Plant Growth," Annual Review of Plant Physiology, Vol. 1, 1950, pp. 285-304. doi:2010.1146/annurev.pp.01.060150.001441

[25] R. Daddow and G. Warrington, "Growth-Limiting Soil Bulk Densities as Influenced by Soil Texture," Watershed Systems Development Group Report, Usda Forest Service, 1984, p. 203.

[26] D. Jorajuria, L. Draghi and A. Aragón, "The Effect of Vehicle Weight on the Distribution of Compaction with Depth and the Yield of Lolium/Trfolium Grassland," Soil 
and Tillage Research, Vol. 41, No. 1-2, 1997, pp. 1-12. doi:10.1016/S0167-1987(96)01085-9

[27] H. Hobbellink, "Beyond the Green Revolution," In: S. A. Lerna, Ed., Barcelona, 1987, p. 219.

[28] L. Brown, C. Flavin, H. French, et al., "The State of the World 1998," Journal of the Science of Food and Agriculture, Vol. 79, No. 10, 1999, pp. 1316-1317. doi:10.1002/(SICI)1097-0010(19990715)

[29] J. Rulli, "Biotechnology and Rural Model at the Origins of the Argentinian Catastrophe," In: Exposición Presentada en el Seminario-Taller: Salud y Seguridad, Modelo Productivo y Soberanía Alimentaria, 2002, p. 2. www.ecoportal.net

[30] F. Martínez Dougnac, "Agricultura Familiar y Concentración Económica en la Región Pampeana," Workshop of Health, Safety, Productive Model and Food Sovereignty,
2001, p. 12.

[31] S. Cloquell, "Agriculture Sustainability as Reproduction Strategy in Family Production," Cuadernos de Desarrollo Rural (45), Eds., Facultad de Estudios Ambientales y Rurales, Pontifica Universidad Javeriana, Bogotá, Colombia, 2002, p. 60.

[32] E. Margiotta and R. Benencia, "Introducción al Estudio de la Estructura Agraria la Perspectiva de la Sociología Rural," Facultad de Agronomía de la Universidad de Buenos Aires, Cátedra de Extensión y Sociología Rurales, 1996, p. 20.

[33] G. F. Botta, A. Tolon Becerra and F. Bellora Melcon, "Seedbed Compaction Produced by Traffic on Four Tillage Regimes in the Rolling Pampas of Argentina," Soil and Tillage Research, Vol. 105, No. 1, 2009, pp. 128-134. doi:10.1016/j.still.2009.06.005 